\title{
GAMBARAN PERSIAPAN ORANG TUA MEMBAWA ANAK USIA TODDLER KETIKA MELAKUKAN KUNJUNGAN WISATA KE BALI
}

\author{
Ida Ayu Dwi Nandy Swari ${ }^{1}$, Ni Luh Putu Shinta Devi ${ }^{2}$, Desak Made Widyanthari ${ }^{3}$ \\ ${ }^{1}$ Mahasiswa Program Studi Sarjana Keperawatan dan Profesi Ners Fakultas Kedokteran Universitas Udayana, \\ ${ }^{2,3}$ Dosen Program Studi Sarjana Keperawatan dan Profesi Ners Fakultas Kedokteran Universitas Udayana \\ Alamat korespondensi: nandyswari29@gmail.com
}

\begin{abstract}
Abstrak
Berlibur bersama anak khususnya usia toddler memiliki tantangan dan masalah yang berbeda. Toddler secara penuh bergantung pada orang tua mereka akan keselamatan fisik. Orang tua memiliki peranan penting dalam mencegah berbagai masalah yang dapat terjadi pada anak saat melakukan kunjungan wisata. Salah satunya yaitu dengan melakukan persiapan sebelum keberangkatan. Penelitian ini bertujuan untuk mengetahui gambaran persiapan orang tua membawa anak usia toddler ketika melakukan kunjungan wisata ke Bali. Penelitian ini merupakan penelitian deskriptif kuantitatif dengan pendekatan cross sectional. Sampel pada penelitian diambil di Kawasan Kuta Selatan, Kabupaten Badung dengan menggunakan teknik consecutive sampling sehingga diperoleh sampel sebanyak 100 wisatawan. Berdasarkan hasil penelitian didapatkan bahwa mayoritas wisatawan mancanegara dan domestik yang berkunjung di Kawasan Kuta Selatan, Kabupaten Badung adalah berusia 34,5 tahun, berpendidikan sarjana (62\%), berstatus bekerja (76\%), berasal dari mancanegara $(55 \%)$, frekuensi kunjungan $>1$ kali (57\%), tidak pernah mendapatkan pre-travel advice (76\%), membawa anak usia 24 bulan, anak berjenis kelamin perempuan (52\%) dan terdapat proporsi yang sama antara lama kunjungan wisatawan yaitu $<10$ hari dan $\geq 10$ hari (50\%). Sebagian orang tua yang membawa anak usia toddler berkunjung ke Bali berada pada kategori persiapan yang buruk (50\%), sedangkan sebagian orang tua yang lainnya (50\%) sudah berada pada kategori persiapan yang baik. Diharapkan kepada orang tua agar mau meningkatkan pengetahuannya mengenai persiapan yang harus dilakukannya ketika membawa anak usia toddler berkunjung ke Bali.
\end{abstract}

Kata Kunci : Orang Tua, Persiapan, Toddler, Wisatawan

\begin{abstract}
Traveling with children especially toddler age has different challenges and problems. Toddlers are fully dependent on their parents for physical safety. Parents have an important role in preventing various problems that can occur in children during a tourist visit. One of them is by making preparations before departure. This study aims to determine the description of the preparation of parents carrying toddler-age children when visiting Bali. This research is a quantitative descriptive study with cross sectional approach. The sample in this study was taken in the area of South Kuta, Badung Regency using consecutive sampling techniques to obtain a sample of 100 tourists. Based on the results of the study it was found that the majority of foreign and domestic tourists visiting the South Kuta Area, Badung Regency were 34.5 years old, had a bachelor's degree (62\%), worked (76\%), were from foreign countries $(55 \%)$, the frequency of visits $>1$ time (57\%), never get pre-travel advice (76\%), bring a child aged 24 months, a female child (52\%) and there is an equal proportion between the length of tourist visits $<10$ days and $\geq 10$ days $(50 \%)$. Some parents who bring toddler-age children visiting Bali are in the poor preparation category $(50 \%)$, while some other parents $(50 \%)$ are already in the good preparation category. It is expected that parents want to increase their knowledge about the preparation they have to do when bringing toddler-age children to visit Bali.
\end{abstract}

Keywords: Parents, Preparation, Toddler, Tourist 


\section{PENDAHULUAN}

Pariwisata merupakan kegiatan orang-orang bepergian dan tinggal di luar lingkungan biasa mereka tinggal selama tidak lebih dari satu tahun berturut-turut dengan tujuan untuk berlibur maupun tujuan lain selain untuk menambah penghasilan (World Tourism Organization dalam Ismayanti, 2010). Indonesia merupakan salah satu negara di dunia yang memanfaatkan pariwisata sebagai sumber pendapatan devisa negara. Indonesia kaya akan daerah wisata sebagai tempat tujuan para wisatawan di dunia, salah satunya yaitu Bali. Bali merupakan destinasi pariwisata yang paling banyak diminati oleh wisatawan mancanegara maupun wisatawan domestik karena memiliki daya tarik dan keunikan tersendiri dalam hal pariwisata (Suwena \& Widyatmaja, 2017).

Wisatawan yang melakukan kunjungan wisata di berbagai negara memiliki karakteristik usia yang berbedabeda, mulai dari anak-anak hingga lanjut usia. Penelitian yang dilakukan oleh Hagmann et al., (2014) menemukan bahwa jumlah anak-anak yang bepergian atau tinggal di luar negara asal mereka mengalami peningkatan secara drastis. Secara umum, anak-anak yang melakukan kunjungan wisata menghadapi sebagian besar risiko kesehatan yang sama dengan orang tua mereka, tetapi konsekuensinya bisa lebih serius. Hal ini disebabkan karena beberapa kondisi yang mungkin sulit dikenali pada anak-anak, terutama pada mereka yang belum bisa berbicara (Center for Disease Control and Prevention, 2013).

Anak-anak yang melakukan kunjungan wisata menempatkan mereka pada risiko penyakit menular seperti malaria, diare, demam berdarah, dan berbagai penyakit kulit (Hagmann et al., 2014). Masalah kesehatan yang paling sering dilaporkan terjadi pada wisatawan anak seperti diarrhea (28\%), dermatologic conditions (25\%), systemic febrile illness $(23 \%)$ dan respiratory disorders (11\%) (Hagmann et al., 2010). Selain memiliki masalah kesehatan, anak juga dapat mengalami travel accident selama wisata, seperti tenggelam di kolam renang dan cedera traumatik akibat kecelakaan kendaraan bermotor (Cortés, Hargen, Hennes., 2006 ; Summer \& Fischer, 2019).

Berlibur bersama anak dari berbagai rentang usia memiliki tantangan dan masalah yang berbeda-beda. Toddler merupakan salah satu kelompok usia yang paling menantang. Masa toddler berada dalam rentang usia satu sampai tiga tahun. Masa ini ditandai dengan peningkatan kemandirian yang diperkuat dengan kemampuan mobilitas fisik dan kognitif yang lebih besar. Pengawasan secara penuh serta pembatasan lingkungan merupakan hal yang sangat penting untuk keselamatan toddler. Toddler secara penuh bergantung pada orang tua mereka akan keselamatan fisik (Potter, P. A \& Perry, A. G, 2005). Orang tua memiliki peranan penting dalam mencegah berbagai masalah yang dapat terjadi pada anak saat melakukan kunjungan wisata. Salah satunya yaitu dengan melakukan persiapan sebelum keberangkatan. Salah satu kawasan wisata di Bali yang banyak dikunjungi oleh wisatawan anak bersama dengan orang tuanya yaitu terletak di Kabupaten Badung.

Kabupaten Badung merupakan salah satu kabupaten di Provinsi Bali yang pendapatan asli daerahnya hampir $90 \%$ diperoleh dari sektor pariwisata. Berdasarkan data survei dari penelitian yang dilakukan oleh Widiarsani (2019), pada empat klinik hotel yang terletak di Kawasan Jimbaran, Kecamatan Kuta Selatan, Kabupaten Badung, diketahui bahwa terdapat beberapa masalah yang 
dialami oleh anak ketika berkunjung ke Bali, sebanyak $28,57 \%$ dialami oleh anak usia toddler. Adapun masalah kesehatan yang paling sering terjadi pada toddler seperti Gastroenteritis Akut (GEA), Otitis, dan Obs. Febris. Berdasarkan data dan permasalahan tersebut, maka Kawasan Kuta Selatan sangat tepat untuk dijadikan tempat penelitian.

Studi pendahuluan telah dilaksanakan di Kawasan Sanur, Kota Denpasar Provinsi Bali. Hasil wawancara kepada 10 orang tua memperlihatkan bahwa sebanyak delapan orang wisatawan anak pernah mengalami sakit ketika

\section{METODE PENELITIAN}

Penelitian ini merupakan penelitian deskriptif kuantitatif dengan pendekatan cross sectional. Populasi penelitian adalah wisatawan domestik dan mancanegara yang berstatus sebagai orang tua dan membawa anak usia toddler di Kawasan Kuta Selatan, Kabupaten Badung pada tanggal 30 Januari - 29 Februari 2020. Pengambilan sampel menggunakan teknik consecutive sampling pada 100 wisatawan. Kriteria inklusi pada penelitian ini adalah wisatawan domestik dan mancanegara yang berstatus sebagai orang tua dan membawa anak usia toddler, bersedia menjadi responden dan menandatangani informed consent. Kriteria eksklusi pada penelitian ini yaitu wisatawan yang tidak memiliki kemampuan berbahasa Indonesia atau berbahasa Inggris.

Data dikumpulkan dengan menggunakan kuesioner yang disusun sendiri oleh peneliti berdasarkan panduan dari CDC (2013) dan beberapa hasil berkunjung ke Bali, sakit yang diderita pun beraneka ragam, mulai dari diare, batuk pilek, infeksi telinga, hingga insiden jatuh. Seluruh responden mengatakan tidak pernah menerima pre-travel advice ketika akan berkunjung ke Bali sehingga rata-rata dari mereka mengatakan tidak mengetahui dengan pasti hal apa saja yang sebenarnya harus dipersiapkan ketika mengajak anak berlibur. Berdasarkan uraian tersebut, maka peneliti tertarik untuk melakukan penelitian mengenai "Gambaran Persiapan Orang Tua Membawa Anak Usia Toddler ketika Melakukan Kunjungan Wisata ke Bali”.

penelitian. Kuesioner ini memiliki 22 daftar pertanyaan dengan pilihan jawaban ya/tidak beserta alasannya. Informed consent dan kuesioner yang digunakan dalam penelitian ini telah diterjemahkan ke dalam Bahasa Inggris oleh penerjemah dari UPT Diklatyan Bahasa Universitas Udayana. Informed consent diisi oleh responden sebelum mengisi kuesioner. Penelitian ini telah lolos uji etik dengan No.409/UN 14.2.2.VII.14/LP/2020.

Analisis data menggunakan analisis statistik deskriptif menggunakan bantuan program SPSS ver.23 dengan tingkat kepercayaan $95 \%(p \leq 0,05)$. Data persiapan orang tua dikategorikan menjadi persiapan baik dan persiapan buruk berdasarkan total skor. Pembagian kategori didasarkan atas nilai cut of point median. Dikategorikan persiapan baik apabila skor yang diperoleh $\geq$ median, dan dikategorikan persiapan buruk apabila skor yang diperoleh < median. 


\section{HASIL PENELITIAN}

Tabel 1. Karakteristik Responden

\begin{tabular}{lccc}
\hline Variabel & Median & Minimum & Maksimum \\
\hline Usia & & & \\
\hline Orang Tua & 34,50 & 21 & 55 \\
Anak & 24,00 & 12 & 36 \\
& & & \\
\hline
\end{tabular}

Tabel 1. menunjukkan nilai tengah usia orang tua 34,50 tahun, usia orang tua termuda adalah 21 tahun dan usia tertua adalah 55 tahun, sedangkan nilai tengah usia anak adalah 24 bulan, usia anak termuda adalah 12 bulan dan usia tertua adalah 36 bulan.

Tabel 2. Karakteristik Responden

\begin{tabular}{|c|c|c|}
\hline Variabel & Frekuensi(n) & Persentase (\%) \\
\hline \multicolumn{3}{|c|}{ Pendidikan Orang Tua } \\
\hline SD & 1 & 1,0 \\
\hline SMP & 2 & 2,0 \\
\hline SMA & 18 & 18,0 \\
\hline Diploma & 17 & 17,0 \\
\hline Sarjana & 62 & 62,0 \\
\hline \multicolumn{3}{|c|}{ Status Pekerjaan Orang Tua } \\
\hline Bekerja & 76 & 76,0 \\
\hline Tidak bekerja & 24 & 24,0 \\
\hline \multicolumn{3}{|l|}{ Asal Wisatawan } \\
\hline Mancanegara & 55 & 55,0 \\
\hline Domestik & 45 & 45,0 \\
\hline \multicolumn{3}{|c|}{ Lama Kunjungan } \\
\hline$<10$ hari & 50 & 50,0 \\
\hline$\geq 10$ hari & 50 & 50,0 \\
\hline \multicolumn{3}{|c|}{ Frekuensi Kunjungan } \\
\hline $1 \mathrm{kali}$ & 43 & 43,0 \\
\hline$>1$ kali & 57 & 57,0 \\
\hline \multicolumn{3}{|c|}{ Status Pre-travel Advice } \\
\hline Pernah & 24 & 24,0 \\
\hline Tidak pernah & 76 & 76,0 \\
\hline \multicolumn{3}{|c|}{ Jenis Kelamin Anak } \\
\hline Laki-laki & 48 & 48,0 \\
\hline Perempuan & 52 & 52,0 \\
\hline Total & 100 & 100,0 \\
\hline
\end{tabular}


Tabel 2. menunjukkan bahwa mayoritas wisatawan adalah berpendidikan sarjana $(62 \%)$, berstatus bekerja $(76 \%)$, berasal dari mancanegara $(55 \%)$, frekuensi kunjungan $>1$ kali $(57 \%)$, tidak pernah mendapatkan pre-travel advice (76\%), membawa anak berjenis kelamin perempuan $(52 \%)$ dan terdapat proporsi yang sama antara lama kunjungan wisatawan yaitu $<10$ hari dan $\geq 10$ hari dengan jumlah masing-masing sebanyak $(50 \%)$.

Tabel 3. Kategori Persiapan Orang Tua

\begin{tabular}{lcc}
\hline Variabel & Frekuensi(n) & Persentase $(\boldsymbol{\%})$ \\
& & \\
\hline Kategori Persiapan Orang Tua & & 50,0 \\
\hline Persiapan Buruk & 50 & 50,0 \\
Persiapan Baik & 50 & $\mathbf{1 0 0 , 0}$ \\
\hline Total & $\mathbf{1 0 0}$ & \\
\hline
\end{tabular}

Berdasarkan tabel 3. diketahui sebanyak 50 orang tua $(50 \%)$ berada pada kategori persiapan yang buruk, sedangkan 50 orang

\section{PEMBAHASAN}

Berdasarkan hasil penelitian ini didapatkan bahwa mayoritas wisatawan mancanegara dan domestik yang berkunjung di Kawasan Kuta Selatan, Kabupaten Badung adalah berusia 34,50 tahun, berpendidikan sarjana, berstatus bekerja, berasal dari mancanegara, frekuensi kunjungan $>1$ kali, tidak pernah menerima pre-travel advice dari petugas kesehatan, membawa anak berusia 24 bulan, anak berjenis kelamin perempuan dan terdapat proporsi yang sama antara lama kunjungan wisatawan yaitu $<10$ hari dan $\geq 10$ hari.

Penelitian Tunjungsari (2018), menyebutkan bahwa karakteristik wisatawan yang datang ke Bali dari segi usia banyak yang relatif muda dan aktif. Penelitian Putra \& Suryawan (2018), menyatakan bahwa wisatawan yang tua yang lainnya (50\%) sudah berada pada kategori persiapan baik.

berkunjung ke Bali dominan bekerja, yaitu sebagai pegawai swasta yang memiliki gaji yang cukup besar untuk digunakan berlibur. Asal wisatawan yang berkunjung ke Bali didominasi oleh wisatawan mancanegara, karena karakteristik dari wisatawan mancanegara yang menyukai daya tarik wisata alam dan bersifat petualang (Sanam, 2018). Lama kunjungan wisatawan ke Bali sangat beragam tergantung pada tujuan mereka melakukan perjalanan (Suherlan, 2014). Sebagian besar wisatawan mengatakan memiliki minat untuk kembali melakukan

kunjungan ke Bali (Sanam, 2018). Mayoritas wisatawan tidak mengunjungi 
klinik untuk melakukan konsultasi terkait dengan perjalanan wisata (Castelli, 2004).

Hasil penelitian menunjukkan bahwa dari 100 orang tua $(100 \%)$ yang membawa anak usia toddler berkunjung ke Bali, sebanyak 50 orang tua $(50 \%)$ memiliki persiapan yang baik, dan sisanya yaitu sebanyak 50 orang tua $(50 \%)$ memiliki persiapan yang buruk. Adapun mayoritas barang yang dipersiapkan seperti: mainan, air dan makanan ringan, body lotion, selimut, baju hangat, kaos kaki, tabir surya (sunscreen), termometer, popok, fotokopi dokumen penting (paspor / visa / catatan imunisasi), lotion/spray anti nyamuk (insect repellent), obat-obatan dan imunisasi. Persiapan yang lainnya seperti bantal leher, pelembab bibir (lip balms), helm, oralit, kursi pengikat (chair restrain system), susu formula, label identifikasi (nametag / gelang), pelampung baju dan cairan pembersih tangan bebasis alokohol (hand sanitizer) masih banyak yang tidak mempersiapkan.

Kategori persiapan buruk didapatkan oleh orang tua dengan rata-rata usia 35,76 tahun, berpendidikan sarjana, berstatus bekerja, berasal dari mancanegara, memiliki lama kunjungan $<10$ hari, frekuensi kunjungan $>1$ kali, tidak pernah menerima pre-travel advice dari petugas kesehatan, membawa anak dengan rata-rata usia 27,74 bulan dan terdapat proporsi yang sama antara anak berjenis kelamin laki-laki dan perempuan. Menurut Nasihah (2017), dalam Jurnal Ners dan Kebidanan menyebutkan bahwa orang tua yang berpendidikan tinggi justru memiliki perilaku yang lebih rendah dalam perawatan anak, hal ini bisa terjadi karena kurangnya informasi dan pengetahuan, pengalaman, serta pengaruh budaya di lingkungan sekitarnya. Menurut Himawan (2006), ketika orang tua yang memiliki peran dominan dalam mengasuh anak (baik itu ayah/ibu) bertatus bekerja, maka akan berdampak terhadap pembinaan dan pemeliharaan anak.

Dilihat dari asal wisatawan, beberapa wisatawan mancanegara dapat memiliki perilaku persiapan wisata yang buruk karena keinginan untuk melakukan perjalanan yang lebih praktis, tanpa membawa banyak barang. Wisatawan yang berkunjung ke Bali >1 kali dapat memiliki persiapan yang buruk karena merasa sudah mengetahui situasi dan kondisi Bali sehingga tidak perlu melakukan persiapan wisata secara khusus. Menurut McIntosh (2015), pre-travel advice membuat para wisatawan mengetahui prosedur pencegahan dan tanggapan perilaku untuk mengurangi risiko tersebut, salah satunya yaitu dengan melakukan persiapan keberangkatan, sehingga sebagian besar wisatawan yang tidak pernah menerima pre-travel advice cenderung memiliki persiapan wisata yang buruk.

Kategori persiapan baik didapatkan oleh orang tua dengan rata-rata usia 33,72 tahun, berpendidikan sarjana, berstatus bekerja, berasal dari mancanegara, memiliki lama kunjungan $>10$ hari, frekuensi kunjungan $>1$ kali, tidak pernah menerima pre-travel advice dari petugas kesehatan, membawa anak dengan rata-rata usia 23,30 bulan dan anak berjenis kelamin perempuan. Pendapat Wong (2012), usia yang paling memuaskan untuk membesarkan anak adalah antara 18 dan 35 tahun, karena orang tua dianggap berada dalam kesehatan yang optimum. Menurut Notoatmodjo (2012), seseorang dengan tingkat pendidikan yang lebih tinggi memiliki pengetahuan dan perilaku yang baik tentang kesehatan yang akan mempengaruhi perilakunya. Menurut Simamora (2018), orang tua yang bekerja dan mampu secara finansial akan lebih memperhatikan kebutuhan anak-anaknya. Berdasarkan artikel Visitpare (2018), wisatawan mancanegara rata-rata memiliki karakter disiplin, perhatian terhadap 
kesehatan dan sanitasi, serta menyukai informasi yang spesifik dan akurat yang dapat mempengaruhi perilaku persiapan wisata mereka.

Wisatawan dengan lama kunjungan $\geq 10$ hari memiliki persiapan yang lebih baik, karena lama kunjungan juga dilakukan. Wisatawan dengan frekuensi kunjungan $>1$ kali memiliki pengalaman mengenai persiapan yang harus dibawa sehingga mereka dapat belajar dari pengalaman tersebut. Wisatawan yang menentukan persiapan yang harus

tidak pernah menerima pre-travel advice dari petugas kesehatan dapat memiliki persiapan wisata yang baik karena adanya informasi yang didapat dari kerabat, internet ataupun dari pengalaman secara langsung yang dialaminya ketika berwisata. Kategori persiapan baik mayoritas diperoleh oleh anak yang berjenis kelamin perempuan, anak perempuan memiliki kebutuhan yang lebih kompleks dibandingkan dengan anak laki-laki, sehingga persiapan yang dilakukan pun akan cenderung berbeda.

\section{SIMPULAN DAN SARAN}

Kesimpulan yang dapat diambil yaitu sebagian orang tua yang membawa anak usia toddler berkunjung ke Bali berada pada kategori persiapan yang buruk yaitu sebanyak 50 orang (50\%), sedangkan sebagian orang tua yang lainnya $(50 \%)$ sudah berada pada kategori persiapan yang baik.

\section{DAFTAR PUSTAKA}

Castelli, F. (2004). Human Mobility and Disease: A Global Challenge. Journal of Travel Medicine, 11(1), $1-2$.

https://doi.org/10.2310/7060.2004. 13610

Center for Disease Control and Prevention. (2013). Traveling With Children. CDC.

https://wwwnc.cdc.gov/travel/page/ children

Cortés, L. M., Hargarten, S. W., \& Hennes, H. M. (2006). Recommendations prevention for travelers. Journal of Travel Medicine, 13(1), 21-34. https://doi.org/10.1111/j.17088305.2006.00002.x

Hagmann, S. H. F., Leshem, E., Fischer, P. R., Stauffer, W. M., Barnett, E. D., \& Christenson, J. C. (2014). Preparing children for international travel: Need for training and pediatric-focused research. Journal of Travel Medicine, 21(6), 377-383. https://doi.org/10.1111/jtm.12155 for water safety and drowning 
Hagmann, S., Neugebauer, R., Schwartz, E., Perret, C., Castelli, F., Barnett, E. D., Stauffer, W. M., \& GeoSentinel Surveillance Network. (2010). Illness in children after international travel: Analysis from the GeoSentinel Surveillance Network. Pediatrics, 125(5), e1072-1080.

https://doi.org/10.1542/peds.20091951

Himawan. (2006). Hubungan Antara Karakteristik Ibu dengan Status Gizi Balita di Kelurahan Sekaran Kecamatan Gunungpati Semarang. [Other, Universitas Negeri Semarang]. https://lib.unnes.ac.id/3363/

Ismayanti. (2010). Pengantar pariwisata. Gramedia Widiasarana Indonesia (Grasindo).

McIntosh, I. B. (2015). The Pre-Travel Health Consultation. Journal of Travel Medicine, 22(3), 143-144. https://doi.org/10.1111/jtm.12182

Nasihah, L. (2017). Hubungan Tingkat Pendidikan dengan Perilaku Ibu dalam Pemberian ASI di BPM Ny. Andre Kediri Tahun 2015. Jurnal Kesehatan Ibu Dan Anak (Mother and Child Medical Science Journal), 2(2), 054-063.

Notoatmodjo, S. (2012). Promosi Kesehatan dan Perilaku Kesehatan. PT. Rineka Cipta.

Potter, P. A \& Perry, A. G. (2005). Fundamental of Nursing: Concepts, process, and practice. EGC.

Putra, A. A., \& Suryawan, I. B. (2018). Karakteristik wisatawan pada program city tour Kota Denpasar. Jurnal Destinasi Pariwisata, 6(2).

Sanam, S. R. (2018). Karakteristik dan persepsi wisatawan di destinasi wisata Tanah Lot. Politeknik Negeri Bali.
Simamora, N. N. L. U. (2018). PENGARUH PENDIDIKAN ORANG TUA, PENDAPATAN ORANG TUA DAN EKSPEKTASI KARIR TERHADAP MINAT MELANJUTKAN KE PERGURUAN TINGGI PADA SISWA KELAS XI AKUNTANSI SMKN 1 WONOSARI TAHUN AJARAN 2016/2017 [Skripsi, Fakultas Ekonomi UNY]. https://eprints.uny.ac.id/54893/

Suherlan, A. (2014). Analisis karakteristik perilaku dan motivasi perjalanan wisata asal Sulawesi Utara ke Jakarta. 4(3).

Summer, A., \& Fischer, P. R. (2019). 23The Pediatric and Adolescent Traveler. In J. S. Keystone, P. E. Kozarsky, B. A. Connor, H. D. Nothdurft, M. Mendelson, \& K. Leder (Eds.), Travel Medicine (Fourth Edition) (pp. 237-246). Elsevier. https://doi.org/10.1016/B978-0323-54696-6.00023-9

Suwena, I. K., \& Widyatmaja, I. (2017). Pengetahuan Dasar Ilmu Pariwisata (Revisi). Pustaka Larasan.

Tunjungsari, K. (2018). Karakteristik dan Persepsi Wisatawan Mancanegara di Kawasan Sanur dan Canggu, Bali. Jurnal Pariwisata Terapan, 2(2).

Visitpare. (2018). Memahami karakter dan budaya wisatawan mancanegara. https//visitpare.com/seni-danbudaya/memahami-karakterbudaya-wistatawan-mancanegara/

Widiarsani, N. P. S. (2019). Faktor-faktor yang berhubungan dengan kejadian travelers' diarrhea pada wisatawan mancanegara di Kawasan Jimbaran, Kecamatan Kuta Selatan, Kabupaten Badung. 
Wong, D. L. (2012). Buku ajar keperawatan pediatrik (6th ed.). EGC. 